\title{
Assessment of water resources and seasonal prediction of rainfall in India
}

\author{
P. R. Rakhecha ${ }^{1, a}$ \\ ${ }^{1}$ independent researcher: D-82, Shastrinagar, Jodhpur-342003, India \\ ${ }^{a}$ formerly at: Indian Institute of Tropical Meteorology, Pune, India \\ Correspondence to: Pukhraj Rakhecha (rakhechapukhraj@gmail.com) \\ Published: 17 October 2016
}

\begin{abstract}
From the analysis of rainfall data available at about 5000 stations, this paper is prepared to provide comprehensive assessment of water availability in different states of India as well as for the country as a whole. Changes in water availability per person are occurring mainly as a consequence of changes in population. The water availability per capita in India was over $6000 \mathrm{~m}^{3}$ per annum in 1951, it now stands at about $1900 \mathrm{~m}^{3}$ per capita. Nevertheless, this amount is nearly twice the water need by the people of developed countries. The developed countries require about $1000 \mathrm{~m}^{3}$ of freshwater per capita per year. The increasing demand for water is in the 4 states of Haryana, UP, Bihar and West Bengal in the face of increasing population and possible changes in climate, the water available in these states is to be used most economically and judiciously so that the vagaries of nature do not put any severe strain.
\end{abstract}

\section{Introduction}

Freshwater is essential for most human purposes and currently it is used in five major sectors: domestic (including drinking water), agriculture, industry, hydropower generation and ecosystem conservation. In recent years there has been an extraordinary increase of interest in the reliable assessment, optimum utilization, and efficient management of water resources in almost every country of the world including India. This is natural since during the past 2 decades the water requirements of every country have enormously increased as a result of population growth and expansion in various important fields of human activity. Of late some hydrologists have come to believe that the world is fast coming to a stage where there is going to be an actual shortage of water. It is in this context we have to view the assessment and management of water resources of India which are unfortunately unevenly distributed by nature. We know that rainfall brings water to the land and the occurrence of rainfall can be considered to be a process of weather systems.

India with $2.4 \%$ of the world surface area of 135.79 million $\mathrm{km}^{2}$ and one sixth $(16 \%)$ of the world's population and diversity of topography, soils, climate, etc., has always been facing challenges in the area of water availability received from the southwest (June-September) and northeast (October-December) monsoons. For example, the water availability per capita in India was over $6000 \mathrm{~m}^{3}$ per annum in 1951, it now stands at about $1900 \mathrm{~m}^{3}$ per capita (see Table 2). Careful use of water resources requires a detailed account of various characteristics of climate systems and the quantitative distribution of rainfall over the country. Moreover, the rainfall in a given area is not the same every year and it may range from half of the normal in one year to twice the normal the next year. This leads to either too much water from high rainfall or too little water from low rainfall resulting in droughts. The rainfall therefore is one of the most irregular climatic variables and this inter-annual variability in rainfall makes rainfall prediction very important for policy makers.

The objective of this paper therefore is to provide comprehensive assessment of water resources that is how much water from rainfall is received by the country as a whole as well as by each state of the country and what the estimates are of surface water and groundwater for utilization so that the information can be useful to manage this important resource in a sustainable manner as also to solve water sharing issues and disputes between the states. India with a total area 


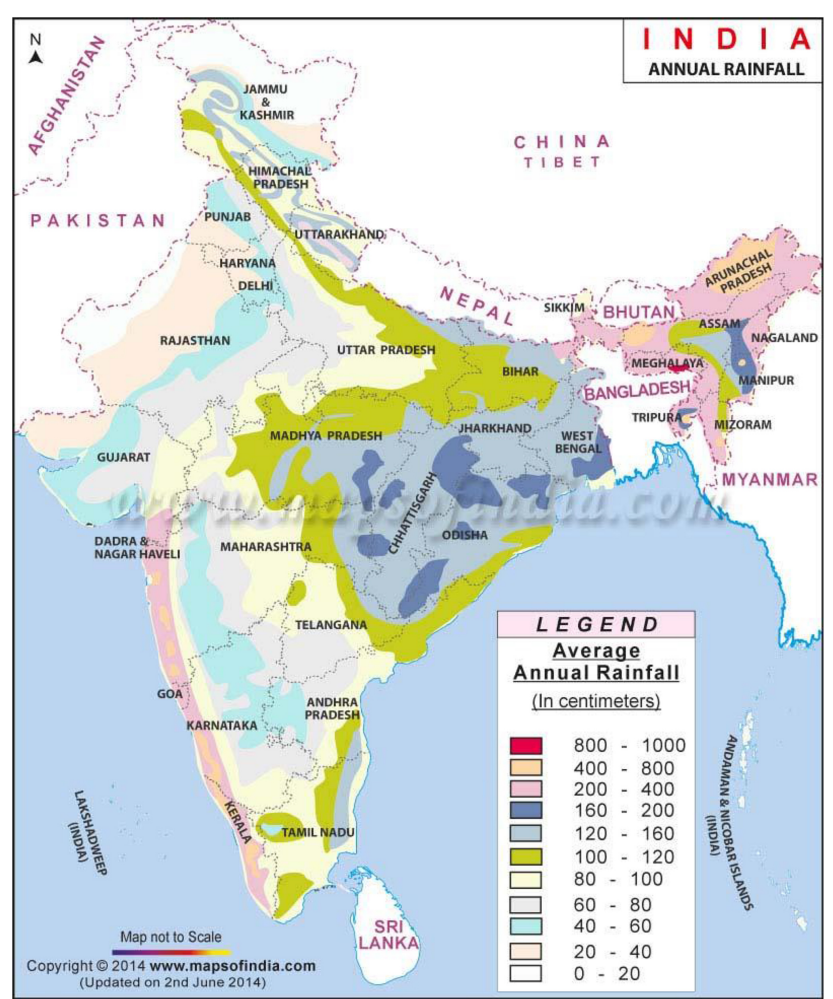

Figure 1. Different states of India and the annual rainfall $(\mathrm{cm})$ over India.

of $3287263 \mathrm{~km}^{2}$ is divided into 29 states and 7 union territories (see Fig. 1).

\section{Rain gauge network in India}

The assessment of water resources requires measurement of rainfall. Rainfall measurement in India began towards the end of the 18th century when the first rainfall station was set up in 1784 at Calcutta (Kolkata). Thereafter, at Madras (Chennai) in 1792, at Bombay (Mumbai) in 1823 and at Shimla in 1840. With the establishment of the India Meteorological Department (IMD) in 1875, the rainfall station network grew rapidly. At the time of independence in 1947, there were around 3000 rainfall stations. Observations of rainfall from these stations are available extending over more than 100 years. The need for increasing the rainfall stations for agriculture and water resources development work was felt after 1947. The rain gauge network at present comprises of about 5000 stations whose data are published, processed and analyzed by the IMD.

\section{Climate systems}

From north to south, the Indian climate shifts from subtropical to tropical. For the most part of the country the year can be divided into the four seasons viz., winter (January to February), summer (March to May), southwest monsoon or rainy (June to September) and northeast monsoon (October to December). The winter season is characterized by low temperatures averaging around $10-15^{\circ} \mathrm{C}$ in the north to around $20-25^{\circ} \mathrm{C}$ in the south. The month of March marks the beginning of summer and the temperature starts rising progressively from April through June, averaging around 30$40^{\circ} \mathrm{C}$. The southwest monsoon months constitute the major rainy season which brings water to the Indian landscape. Most parts of the country receive about $75-80 \%$ of their annual rainfall during this season. From time to time monsoon weather systems (depressions and tropical storms) from the Bay of Bengal and the Arabian sea move across the country and bring heavy rainfall and floods into the Indian rivers. The northeast monsoon period is comparatively drier throughout the country but serves as a major source of rainwater for the states of Andhra Pradesh, Telangana and Tamil Nadu.

\section{Distribution and assessment of annual rainwater resources over India}

The source of all freshwater in India is rainfall from the southwest and northeast monsoons. The mean annual rainwater distribution over the country is shown in Fig. 1 which apparently is shaped by the country's physical geography. Figure 1 shows that rainwater is distributed unevenly across the country. In the high reaches of Western Ghats there are places which receive rainwater of the order of $600 \mathrm{~cm}$. However, on the lee side the rainwater decreases sharply to as low a figure as $60 \mathrm{~cm}$. Again in the southern slopes of Khasi-Jaintia Hills in Meghalaya the influence of topography is predominant and there are stations where the normal annual rainwater is of the order of $1000 \mathrm{~cm}$. Whereas on the northern side the influence of Himalayan ranges is apparent in the rainwater pattern in the sub-montane regions, on the northwestern side the rainwater rapidly decreases and over the west Rajasthan desert the annual amounts decreases to about $10 \mathrm{~cm}$.

Dhar and Rakhecha $(1975,1979)$ have estimated the average monthly, seasonal and annual rainwater of the contiguous Indian area using 60 years (1901-1960) rainfall data of about 3000 stations (see Table 1). The mean annual rainwater for the country as a whole is about $117 \mathrm{~cm}$ with a CV of $10 \%$. This table shows that each of the monsoon months contributes more than $15 \%$ of annual rainwater. The $\mathrm{CV}$ of these four months varies from 13 to $22 \%$ while other months have high variability. The average seasonal rainwater amounts are $2.8,12.6,89.7$ and $12.3 \mathrm{~cm}$ for winter, summer, southwest monsoon and northeast monsoon contributing 2.4, 10.7, 76.4 and $10.5 \%$ respectively to the annual rainwater amount. A $\mathrm{CV}$ value of $10 \%$ demonstrates that in approximately 68 out of every 100 years, the rainfall in the country will range from an excess of $10 \%$ over the mean annual rainfall to a deficiency of $10 \%$. The deviation will be greater than $10 \%$ in the remaining 32 years: a deficit greater than $10 \%$ in approx- 
imately 16 of those years and an excess greater than $10 \%$ in the other 16 years.

The average annual rainfall of the country is about $117 \mathrm{~cm}$ which is almost one and half times larger than the world average of $80 \mathrm{~cm}_{\text {year }}{ }^{-1}$. The total volume of annual rainwater calculated from the product of the rainfall and the land area of India $\left(3287263 \mathrm{~km}^{2}\right)$ is approximately $4000 \mathrm{~km}^{3}$ with a standard deviation of $385 \mathrm{~km}^{3}$. Of the total rainwater received by the country, about $1400 \mathrm{~km}^{3}$ of water is lost by evaporation and transpiration and approximately $730 \mathrm{~km}^{3}$ of water goes into the soil. After deduction for evapotranspiration and infiltration, according to CWC (2002) the average annual surface runoff in the river systems of the country is $1869 \mathrm{~km}^{3}$. This shows that roughly $47 \%$ of the annual rainfall is converted into surface runoff. The ground water recharge from rainfall in India made by the Central Ground Water Board, New Delhi is about $432 \mathrm{~km}^{3}$ (CGWB, 1991; Chadha, 2006). Thus the total water resource of India is $2301 \mathrm{~km}^{3}$. The present water availability for a population of 1210 million people in India stands approximately $1902 \mathrm{~m}^{3}$ per capita per year. Developed countries require approximately $1000 \mathrm{~m}^{3}$ of freshwater per capita per year. In this sense, water resources of India are relatively high.

The series of annual rainwater volume over the country is Gaussian. The values of annual rainwater volume which can be exceeded at probability of 5, 10, 20, 30, 40, 50, 60, 70, 80, 90 and $95 \%$ levels have been calculated as 4635, 4492, 4325, 4203, 4098, 4000, 3902, 3798, 3677, 3507 and $3365 \mathrm{~km}^{3}$ respectively.

\section{Population and freshwater availability trends in India}

India's finite and fragile water resources are stressed and depleting while population has been growing rapidly. Population growth is the key to the whole equation of water availability and its use because of the fact that India's population has grown four fold over the past 70 years. The population of India which at the turn of the twentieth century was around 238.4 million increased to reach 1210 million at the dawn of the twenty first century. The population of India as recorded at each decennial census from 1901 has grown steadily except for a decrease during 1911-1921. Decadal growth of population from 1901 is shown in Table 2. This table shows that per capita water availability is reducing with population growth. The water per capita in India was over $6000 \mathrm{~m}^{3}$ per annum in 1951, it is now stands at about $1902 \mathrm{~m}^{3}$ per capita. With every increase in population there is corresponding decline in per capita availability of water (Fig. 2). It is estimated that the population of India would be around 1.5 to 1.8 billion in 2050. The per capita availability of water will then be around $1200 \mathrm{~m}^{3}$ year $^{-1}$, consequently effective water management in India is of greater urgency than in most of other countries.

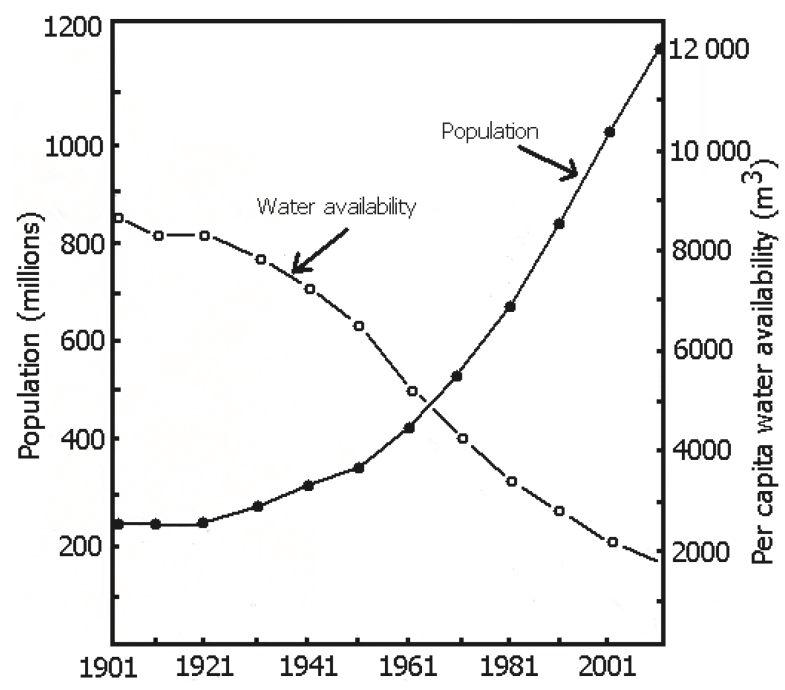

Figure 2. Population and water availability trends 1901-2011.

\section{Assessment of annual water resources of different states of India}

It is important to know how much water from rainfall is received by each state of the country, and determine estimates of surface water and groundwater for utilization. Table 3 gives area average annual rainfall values and the coefficient of variability of annual rainfall for each of the 29 states, as well as for the country as a whole estimated from point rainfall values (IMD, 1962, 1981). Table 3 shows that the rainfall in India varies widely. The highest average annual rainfall is $300 \mathrm{~cm}$ in Kerala and the lowest annual rainfall is $55 \mathrm{~cm}$ in Haryana. About $10 \%$ of India has an annual rainwater greater than $200 \mathrm{~cm}$ while about $40 \%$ has less than $100 \mathrm{~cm}$. These proportions play an important part in the relative water availability statuses of the 29 states.

The rainfall-runoff ratio has been determined to be approximately $47 \%$ for the country as a whole. Average annual rainfall values are available for each state of India in Table 3. By assuming a rainfall-runoff ratio of $47 \%$, estimates of annual runoff water available in each state of the country can be made. A summary of the population, the average annual rainfall and runoff, the average annual amount of groundwater and per capita annual water availability in each state of India are given in Table 3. Figures suggest that the disparity among states in per capita water availability is wide. The highest water availability is $65071 \mathrm{~m}^{3}$ year $^{-1}$ per person in Arunachal Pradesh, and the lowest is $831 \mathrm{~m}^{3}$ year $^{-1}$ per person in Bihar. According to Table 3, four contiguous states (Haryana, Uttar Pradesh, Bihar and West Bengal) have total water availability less than $1000 \mathrm{~m}^{3}$ year $^{-1}$ per person, 3 between 1000 and $1500 \mathrm{~m}^{3}$ year $^{-1}$ per person, eight between 1500 and $3000 \mathrm{~m}^{3}$ year $^{-1}$ per person, five between 3000 and $5000 \mathrm{~m}^{3}$ year $^{-1}$ per person and 9 have over $5000 \mathrm{~m}^{3}$ year $^{-1}$ per person. Areas with water resources in the 
Table 1. Rainwater statistics of the contiguous Indian area-1901 to 1960 (Dhar and Rakhecha, 1975, 1979).

\begin{tabular}{lcccccc}
\hline Months & $\begin{array}{c}\text { Mean rainfall } \\
(\mathrm{cm})\end{array}$ & $\begin{array}{c}\% \text { of } \\
\text { annual }\end{array}$ & $\begin{array}{c}\text { SD } \\
(\mathrm{cm})\end{array}$ & $\begin{array}{c}\text { CV } \\
(\%)\end{array}$ & $\begin{array}{c}\text { Highest rainfall } \\
(\mathrm{cm})\end{array}$ & $\begin{array}{c}\text { Lowest rainfall } \\
(\mathrm{cm})\end{array}$ \\
\hline January & 1.1 & 0.9 & 1.1 & 100 & 5.3 & 0.4 \\
February & 1.7 & 1.7 & 1.3 & 77 & 5.1 & 0.3 \\
March & 2.5 & 2.1 & 1.1 & 44 & 5.7 & 0.7 \\
April & 3.8 & 3.2 & 0.9 & 24 & 6.9 & 1.8 \\
May & 6.3 & 5.4 & 1.6 & 25 & 10.3 & 3.4 \\
June & 16.6 & 14.1 & 3.5 & 21 & 22.5 & 9.7 \\
July & 29.7 & 25.3 & 3.8 & 13 & 35.9 & 17.1 \\
August & 26.0 & 22.3 & 3.7 & 14 & 33.9 & 17.8 \\
September & 17.4 & 14.8 & 3.9 & 22 & 27.1 & 10.3 \\
October & 7.8 & 6.7 & 3.0 & 39 & 16.0 & 2.1 \\
November & 3.1 & 2.6 & 1.7 & 55 & 7.5 & 0.3 \\
December & 1.4 & 1.2 & 0.8 & 57 & 3.7 & 0.1 \\
Winter (Jan-Feb) & 2.8 & 2.4 & 1.2 & 43 & 6.1 & 0.7 \\
Summer (Mar-May) & 12.6 & 10.7 & 2.1 & 17 & 14.8 & 5.6 \\
Southwest (Jun-Sep) & 89.7 & 76.4 & 8.5 & 9 & 100.5 & 65.1 \\
Northeast (Oct-Nov) & 12.3 & 10.5 & 3.5 & 29 & 21.0 & 5.0 \\
\hline Annual & 117.4 & 100 & 11.7 & 10 & $144.6(1917)$ & $96.1(1918)$ \\
\hline
\end{tabular}

Table 2. Population and water availability trends in India (M.I\&B, 2012).

\begin{tabular}{lrrrr}
\hline $\begin{array}{l}\text { Census } \\
\text { years }\end{array}$ & $\begin{array}{r}\text { Population } \\
\text { (million) }\end{array}$ & $\begin{array}{r}\text { Decadal } \\
\text { growth }(\%)\end{array}$ & $\begin{array}{r}\text { Progressive growth } \\
\text { rate over } 1901(\%)\end{array}$ & $\begin{array}{r}\text { Per capita water } \\
\text { availability }\left(\mathrm{m}^{3}\right)\end{array}$ \\
\hline 1901 & 238.4 & - & - & 9652 \\
1911 & 252.1 & 5.8 & 5.8 & 9127 \\
1921 & 251.3 & -0.31 & 5.4 & 9156 \\
1931 & 279.0 & 11.0 & 17.0 & 8247 \\
1941 & 318.7 & 14.2 & 33.7 & 7220 \\
1951 & 361.1 & 13.3 & 51.5 & 6372 \\
1961 & 439.2 & 21.6 & 84.3 & 5239 \\
1971 & 548.2 & 24.8 & 129.9 & 4197 \\
1981 & 683.3 & 24.7 & 186.7 & 3368 \\
1991 & 846.4 & 23.9 & 255.0 & 2719 \\
2001 & 1028.7 & 21.5 & 331.5 & 2236 \\
2011 & 1210.0 & 17.6 & 407.5 & 1902 \\
\hline
\end{tabular}

range of 1000 to $1500 \mathrm{~m}^{3}$ year $^{-1}$ per capita begin to experience water stressed condition. Increasing shortages are felt at local levels which can spread to the regional level as the population continues to grow. Jain et al. (2007) have written a comprehensive book which covers the water resources of India in sufficient detail for the benefit of hydrologists.

At the time of India's independence in 1947, the country's population was less than 360 million and water available per capita was over $6000 \mathrm{~m}^{3}$ year $^{-1}$. Now, after 68 years of independence, India's population has increased to approximately 1.2 billion and per capita water availability has fallen to approximately $1902 \mathrm{~m}^{3}$ year $^{-1}$. This per capita water availability will further fall to approximately $1500 \mathrm{~m}^{3}$ year $^{-1}$ by the year 2025 due to increasing population which will exert fur- ther pressure on water availability. This necessitates great changes to be made with a national perspective in this regard.

\section{Seasonal forecasting of Indian monsoon rainfall}

Rainfall forecasts are required in planning and management of rainwater resources for agriculture and other human activities. Hence, in recent years the need for improved forecasting of monsoon rainfall in India has become increasingly important. We shall study some of the methods of weather forecasting for the benefit of hydrologists.

Generally there are three main approaches used for longrange forecast of the southwest monsoon in India. The first is the statistical method which uses the historical relationship between the southwest monsoon and various global weather 
Table 3. Land, Population and Water Resources of 29 states in India (Source: IMD, 1962 and M.I\&B, 2012).

\begin{tabular}{|c|c|c|c|c|c|c|c|c|c|c|}
\hline $\begin{array}{l}\mathrm{Sr} \\
\text { No. }\end{array}$ & State & $\begin{array}{r}\text { Area } \\
\left(\mathrm{km}^{2}\right)\end{array}$ & $\begin{array}{r}\text { People (million) } \\
\text { (2011) }\end{array}$ & $\begin{array}{l}\text { Avg. annual } \\
\text { rainfall }(\mathrm{cm})\end{array}$ & $\begin{array}{l}\mathrm{CV} \\
(\%)\end{array}$ & $\begin{array}{r}\text { Total water } \\
\left(\mathrm{km}^{3} \text { year }^{-1}\right)\end{array}$ & $\begin{array}{l}\text { Runoff } \\
\left(\mathrm{km}^{3} \text { year }^{-1}\right)\end{array}$ & $\begin{array}{l}\text { Ground Water } \\
\left(\mathrm{km}^{3} \text { year }^{-1}\right)\end{array}$ & $\begin{array}{l}\text { Water Resource } \\
\qquad\left(\mathrm{km}^{3} \text { year }^{-1}\right)\end{array}$ & $\begin{array}{l}\text { Per capita water } \\
\left(\mathrm{m}^{3} \text { year }^{-1}\right)\end{array}$ \\
\hline 1 & Andhra Pradesh & 160229 & 49.4 & 88 & 20 & 141.0 & 66.3 & 5.3 & 71.6 & 1449 \\
\hline 2 & Arunachal Pradesh & 83743 & 1.4 & 228 & 11 & 190.9 & 89.7 & 1.4 & 91.1 & 65071 \\
\hline 3 & Assam & 78438 & 31.2 & 252 & 11 & 196.0 & 92.9 & 22.5 & 115.4 & 3699 \\
\hline 4 & Bihar & 94161 & 103.8 & 134 & 13 & 126.2 & 59.3 & 27.0 & 86.3 & 831 \\
\hline 5 & Chattisgarh & 136034 & 25.6 & 135 & 16 & 183.6 & 86.3 & 16.1 & 102.4 & 4000 \\
\hline 6 & Goa & 3702 & 1.5 & 254 & 20 & 9.4 & 4.4 & 0.2 & 4.6 & 3066 \\
\hline 7 & Gujarat & 196024 & 60.4 & 83 & 30 & 162.7 & 76.5 & 20.4 & 96.9 & 1604 \\
\hline 8 & Haryana & 44212 & 25.4 & 55 & 28 & 24.3 & 11.4 & 11.2 & 22.6 & 890 \\
\hline 9 & Himachal Pradesh & 55673 & 6.9 & 175 & 21 & 97.4 & 45.8 & 0.3 & 46.1 & 6681 \\
\hline 10 & Jammu \& Kashmir & 222236 & 12.6 & 100 & 22 & 222.2 & 104.4 & 4.4 & 108.8 & 8635 \\
\hline 11 & Jharkhand & 79714 & 33.0 & 119 & 16 & 94.9 & 44.6 & 6.6 & 51.2 & 1551 \\
\hline 12 & Karnataka & 191791 & 61.2 & 136 & 18 & 260.8 & 122.6 & 16.2 & 138.8 & 2268 \\
\hline 13 & Kerala & 38863 & 33.4 & 300 & 14 & 116.6 & 54.8 & 7.9 & 62.7 & 1877 \\
\hline 14 & Madhya Pradesh & 308144 & 72.6 & 122 & 20 & 375.9 & 176.7 & 34.8 & 211.5 & 2913 \\
\hline 15 & Maharashtra & 307713 & 112.4 & 132 & 21 & 406.2 & 190.9 & 37.4 & 228.3 & 2031 \\
\hline 16 & Manipur & 22327 & 2.7 & 252 & 11 & 56.3 & 26.5 & 3.2 & 29.7 & 11000 \\
\hline 17 & Meghalaya & 22429 & 3.0 & 283 & 11 & 63.5 & 29.8 & 0.5 & 30.3 & 10100 \\
\hline 18 & Mizora & 21081 & 1.1 & 283 & 11 & 59.0 & 28.1 & - & 28.1 & 25545 \\
\hline 19 & Nagaland & 16579 & 2.0 & 283 & 11 & 46.9 & 22.1 & 0.7 & 22.8 & 11400 \\
\hline 20 & Orissa & 155707 & 42.0 & 149 & 14 & 232.0 & 109.1 & 20.1 & 129.2 & 3076 \\
\hline 21 & Punjab & 50362 & 27.7 & 63 & 34 & 31.7 & 14.9 & 18.2 & 33.1 & 1195 \\
\hline 22 & Rajasthan & 342239 & 68.6 & 59 & 31 & 201.9 & 94.9 & 12.6 & 107.5 & 1567 \\
\hline 23 & Sikkam & 7096 & 0.6 & 274 & 12 & 19.5 & 9.2 & - & 9.2 & 15333 \\
\hline 24 & Tamil Nadu & 130058 & 72.2 & 101 & 14 & 131.4 & 61.8 & 26.4 & 88.2 & 1222 \\
\hline 25 & Telangana & 114840 & 35.3 & 93 & 20 & 106.8 & 50.2 & 3.8 & 54.0 & 1530 \\
\hline 26 & Tripura & 10491 & 3.7 & 252 & 11 & 26.4 & 12.4 & 0.7 & 13.1 & 3540 \\
\hline 27 & Uttaranchal & 53483 & 10.2 & 103 & 19 & 55.1 & 25.9 & 28.4 & 54.3 & 5234 \\
\hline 28 & Uttar Pradesh & 238566 & 199.3 & 99 & 20 & 236.2 & 110.0 & 82.6 & 192.6 & 966 \\
\hline 29 & West Bengal & 88752 & 91.4 & 165 & 15 & 146.5 & 68.9 & 23.1 & 92.0 & 1007 \\
\hline- & India & 3287263 & 1210 & 117 & 10 & 4000 & 1869 & 432 & 2301 & 1902 \\
\hline
\end{tabular}

parameters. The second approach is the empirical method which uses time series analysis of past rainfall data to predict the monsoon. The third is the dynamical method, which uses general circulation models of the atmosphere and ocean to predict the southwest monsoon. Prediction models based on the statistical approach have so far yielded the most satisfactory results for the Indian monsoon. However, none of the models can claim $100 \%$ accuracy because there are several factors like the correlations between the parameters and changing predictability of the model over a period of time because of weather anomalies.

\subsection{Statistical method used for predicting the southwest monsoon rainfall}

Prior to 2002, the IMD used to issue the annual forecast using a model based on 16 parameters. The 16 parameters are broadly classified into 3 groups, namely (1) pressure, (2) upper winds and temperatures and, (3) snow cover and atmospheric oscillations. But the model failed in 2002. Since 2003, two new models were introduced which instead of 16 used 8 and 10 parameters to forecast the southwest monsoon in India.

Weather forecasts generally have uncertainty due to small errors in the initial conditions and model approximations. Together they limit the skill of a deterministic forecast system. Ensemble forecasting has emerged as the practical way of estimating the forecast uncertainty and making probabilistic forecasts. Ensemble forecasts are generated based on multiple perturbed initial conditions which sample the errors in the initial conditions to estimate the forecast uncertainty. The skill of the ensemble forecast shows marked improvement over the deterministic forecast. Since 2007, an ensemble forecasting technique is being used to forecast the monsoon.

At present, the predictors used to forecast the monsoon include the surface temperature of the north Atlantic, equatorial southeast Indian Ocean and Central Pacific Ocean along with the air temperature of northwest Europe. Apart from this, the warm water volume of the equatorial Pacific, the air pressure over the north Atlantic and East Asia as well as the wind patterns over the north central Pacific Ocean are the parameters used to predict the southwest monsoon.

\subsection{Forecasting Northeast monsoon rainfall over Tamil Nadu}

Tamil Nadu (see Fig. 1) is the only state of the Indian union which receives more rainfall in the northeast monsoon (October-December) season than in the southwest monsoon (June-September) season. Thus the rainfall received in Tamil Nadu during the northeast monsoon season is of great economic value. Major agricultural operations are normally undertaken during that season. It has been noted that the rainfall 
during northeast monsoon is highly variable. Therefore, if its behavior could be predicted in advance, it would go a long way toward helping the agricultural and industrial activities of the state.

Dhar and Rakhecha (1983) examined the association between the southwest and northeast monsoon rainfall over Tamil Nadu for the 100 year period from 1871 to 1978 . A correlation analysis between the two rainfall series revealed that the southwest monsoon rainfall is negatively correlated with that of the northeast monsoon rainfall. That is an excess or deficit of southwest monsoon rainfall over Tamil Nadu is generally followed by an opposite tendency to the northeast monsoon rainfall. A Chi-square test of dependence further indicated that the rainfalls in the two monsoons are not independent of each other. The negative rainfall relationship can be useful tool in forecasting the northeast monsoon rainfall over Tamil Nadu. The observed southwest monsoon rainfall over Tamil Nadu can be used to provide a forecast of the behavior of the following northeast monsoon season rainfall.

\section{Water use in India}

According to the Ministry of Water Resources, Government of India (2002), about $690 \mathrm{~km}^{3}$ from surface water and $432 \mathrm{~km}^{3}$ from groundwater are considered to be suitable water for public use. It is found that the five major sectors (agriculture, domestic, industry, hydro power generation and environment) use nearly $60 \%$ of the total water estimated at about $1122 \mathrm{~km}^{3}$ in 2010 (Rakesh Kumar et al., 2005). Agriculture is the mainstay of India's economy. As such the first consumer is agriculture which uses about $543 \mathrm{~km}^{3}$ of the total volume. The second largest consumption of water is domestic water of nearly $42 \mathrm{~km}^{3}$. The industry, power generation and environment use about 37,18 and $5 \mathrm{~km}^{3}$ per year respectively. The population in India is steadily increasing which means an increase in the water demand. With an average growth rate of $3.5 \%$ per year in population, Rakesh Kumar et al. (2005) estimated the total water requirements for agriculture, domestic use, industry, power generation and environment would be about 561, 55, 67, 31 and $10 \mathrm{~km}^{3}$ per year respectively in the year 2025 .

\section{Climate change impacts on India's rainfall}

According to the Intergovernmental Panel on Climate Change (IPPC, 2007) the world's climate may be changing in response to land use change and from the increase in carbon dioxide and other green house gases. Emissions of carbon dioxide grew twelve fold between 1900 and 2000 from 534 million metric tons per year in 1900 to 6.59 billion metric tons in 1997. In the same period, the human population has nearly quadrupled from 1.6 billion to 6.1 billion progressively consuming greater quantities of fossil fuels. The IPCC note that greenhouse gases are likely to warm the atmosphere by $2{ }^{\circ} \mathrm{C}$ by 2100 . Therefore, it appears natural that higher temperatures will intensify the global hydrological cycle and in turn considerably influence the variability and strength of the Indian monsoon rainfall. The current question is to see whether or not a climate change exercises any significant influence on the rainfall of India. A large number of studies pertaining to trends and periodicities in either the annual or seasonal rainfall for individual stations (Koteswaram and Alvi, 1969; Jagannathan and Parthasarthy, 1973; Rupa Kumar et al., 1992), for different subdivisions (Dhar et al., 1982; Jain et al., 2013) as well for India as a whole (Mooley and Parthasarathy, 1984; Kumar et al., 2010) showed that there is no statistically significant trend of increase or decrease in Indian rainfall. In addition Rakhecha and Soman (1994) examined annual extreme rainfall data of 1 to 3 days for the period 1901-1980 obtained from 316 stations distributed across the country and discovered that the annual extreme rainfall records of most stations are free from trend and persistence.

\section{Conclusions}

It is a known fact that rainwater in a geographic sense is unevenly distributed in India. The assessment of water resources has shown that the amount of available freshwater has not changed and there is enough fresh water from rainfall in India as a whole to everyone's satisfaction. Nevertheless, four contiguous states of Haryana, Uttar Pradesh, Bihar and West Bengal are characterized as the hot spots of water stressed where urgent action is needed within water sector. However, times have changed as demographic pressure in the last 5 decades (for example 360 million in 1951, 680 million in 1961 and 1210 million at the end of 2011) demonstrates that access to freshwater is a challenge for the current population. The management of water therefore needs cooperation among communities.

\section{Data availability}

The data on rainfall and groundwater play a vital role in the assessment of water resources of any region. Such data in India are available in various publications of India Meteorological Department (IMD) and in the professional journals of meteorology and hydrology. Monthly and annual averages of rainfall and of rainy days for the period 1901-1950 for nearly 3000 rain gauge stations in India are available in the Memoirs of the India Meteorological Department published in 1962 (IMD, 1962) and in the Climatological Atlas of India part A (rainfall) published in 1981. The Groundwater data in respect of different states of India are available in the Bhu-Jal News (special issue on groundwater statistics), a quarterly journal of Central Ground Water Board (CGWB, 1991) published in 1991 by the Ministry of Water Resources, Government of India. These data have been used systematically to study the assessment of water resources of India. 
Acknowledgements. The author thanks Colin Clark, Charldon Hill Research Station, Bruton, England for comments on an earlier draft of the paper. Also thanks to the reviewers for the constructive review of the paper.

\section{References}

Central Ground Water Board (CGWB): Bhu-Jal News (special issue on groundwater statistics), J. CGWB, Ministry of Water Resources Publ. Government. of India, 6, 1-162, 1991.

Central Water Commission (CWC): National Water Policy 2002, Min. of Water Resources Government of India, New Delhi, 2002.

Chadha, D. K.: Development of groundwater resources of India. A overview, groundwater modeling \& management, Capital Publishing Company, New Delhi, 2006.

Dhar, O. N. and Rakhecha, P. R.: A review of hydrometeorological studies of Indian rainfall, Proc Second World Congress on Water Resources organized by International Water Resources Association, held at New Delhi, 449-462, 3, 1975.

Dhar, O. N. and Rakhecha, P. R.: A review of rainfall relationship based upon Indian data, Water Resources Journal ESCAP, Bangkok, 16-25, 1979.

Dhar, O. N. and Rakhecha, P. R.: Foreshadowing northeast monsoon rainfall over Tamil Nadu, India, Mon. Weather Rev., 3, 109-112, 1983.

Dhar, O. N., Rakhecha, P. R., and Kulkarni, A. K.: Fluctuations in northeast monsoon rainfall of Tamil Nadu, J. Climatol., 2, 339345, 1982.

India Meteorological Department (IMD): Monthly and annual averages of rainfall and of rainy days, Memoirs of IMD, 31, 65-208, 1962.
India Meteorological Department (IMD): Climatological Atlas of India, part A (rainfall), 1981.

Intergovernmental Panel on Climate Change (IPCC): Fourth assessment Report on Climate change, Synthesis report, Cambridge Univ, Press, Cambridge, 2007.

Jagnnathan, P. and Parthasarthy, B.: Trends and peridiocities of rainfall over India, Mon. Weather Rev., 101, 371-375, 1973.

Jain, S. K., Agarwal, P. K., and Singh, V. P.: Hydrology \& Water Resources of India, Springer Verlag, Netherlands, 2007.

Jain, S. K., Kumar, V., and Saharia, M.: Analysis of rainfall \& temperature in northeast India, Int. J. Climatol., 33, 968-978, 2013.

Koteswaram, P. and Alvi, S. M. A.: Secular trends and periodicities in rainfall at west coast stations in India, Current Sci., 38, 229$231,1969$.

Kumar, V., Jain, S. K., and Singh, Y.: Analysis of long term rainfall trends in India, Hydrolog. Sci., 55, 484-496, 2010.

Ministry of Information \& Broadcasting, India 2012: A reference Annual, M. I \& B publ. Government of India, New Delhi, 2012.

Ministry of Water Resources: National water policy, Government of India, 1-9, 2002.

Mooley, D. A. and Parthasarathy, B.: Fluctuations in all India summer monsoon rainfall during 1871-1978, Climatic Change, 6, 287-301, 1984.

Rakesh Kumar, Singh, R. D., and Sharma, K. D.: Water resources of India, Curr. Sci. India, 89, 794-811, 2005.

Rakhecha, P. R. and Soman, M. K.: Trends in the annual extreme rainfall events of 1 to 3 days duration over India, Theor. Appl. Climatol., 48, 227-237, 1994.

Rupa Kumar, K., Pant, G. B., Parthasarthy, B., and Sontakke, N. A.: spatial and subseasonal patterns of the long term trends of Indian summer monsoon rainfall, Int. J. Climatol., 12, 257-268, 1992. 